\title{
PENGARUH SKEPTISME PROFESIONAL DAN INDEPENDENSI TERHADAP PENDETEKSIAN KECURANGAN
}

\author{
Maulana Aji Presetyo, Edi Sukarmanto, Mey Maemunah \\ Program Studi Akuntansi, Fakultas Ekonomi dan Bisnis Unisba \\ maulanaajiprasetyo15@gmail.com
}

\begin{abstract}
Abstrak. Tujuan penelitian ini adalah untuk mengetahui pengaruh skeptisme profesional auditor terhadap pendeteksian kecurangan, pengaruh independensi auditor terhadap pendeteksian kecurangan. Penelitian ini dilakukan di Kantor Akuntan Publik kota Bandung dengan metode penelitian deskriptif kuantitatif dan verifikatif. Sumber data yang digunakan sumber data primer. Adapun teknik pengumpulan data yang digunakan adalah kuesioner. Teknik penentuan sampel dalam penelitian ini yaitu non-probability sampling. Pengujian hipotesis yang digunakan adalah analisis regresi linier berganda. Hasil penelitian menunjukkan bahwa (1) skeptisme profesional berpengaruh terhadap pendeteksian kecurangan, (2) Independensi tidak berpengaruh terhadap pendeteksian kecurangan. Saran bagi peneliti selanjutnya diharapkan untuk dapat mengembangkan penelitian dengan menambah variabel-variabel lain yang tidak dibahas dalam penelitian ini dan peneliti selanjutnya sebaiknya memeperluas dan menambah objek yang diteliti dengan menggunakan responden yang berbeda.
\end{abstract}

\section{Kata Kunci : Skeptisme Profesional, Independensi, Pendeteksian Kecurangan.}

\section{Pendahuluan}

Auditor merupakan profesi yang diharapkan banyak orang untuk dapat meletakkan kepercayaan sebagai pihak yang bisa melakukan audit atas laporan keuangan dan dapat bertanggung jawab atas pendapat yang diberikan. Seorang auditor juga harus mampu untuk memberikan keyakinan bahwa laporan keuangan tidak dipengaruhi oleh salah saji baik yang disebabkan oleh kekeliruan atau kecurangan (fraud) yang material dan juga memberikan keyakinan yang memadai atas akuntabilitas manajemen atas aktiva perusahaan.

Pendeteksian kecurangan merupakan kemungkinan auditor untuk dapat melaporkan dan mendeteksi kesalahan atau kecurangan. Kecurangan (fraud) merupakan tindakan yang dilakukan dengan sengaja dan mengakibatkan adanya salah saji material dalam laporan keuangan dimana laporan keuangan ini adalah subjek utama dalam audit. Mendeteksi kecurangan merupakan upaya untuk mendapatkan indikasi awal yang cukup mengenai tindak kecurangan, sekaligus mempersempit ruang gerak para pelaku kecurangan sehingga kita banyak dikejutkan dengan munculnya berbagai jenis manipulasi atau kecurangan dalam dunia usaha (Valey G. Kumaat, $2011: 156$ ).

Banyak perusahaan yang melakukan kesalahan atau kecurangan dalam membuat laporan keuangan, salah satu fenomena yang terjadi ialah sudah hampir empat bulan perdagangan saham PT Inovisi Infracom Tbk (INVS) dihentikan (suspend). Laporan keuangan yang banyak kesalahan jadi penyebab suspensi (finance.detik.com:2015), selain itu Pengawas keuangan Jepang berencana memberi hukuman kepada perusahaan teknologi Toshiba Corp., karena diduga memalsukan laporan keuangan (cnnindonesia.com:2015). Banyak faktor yang bisa menjadi penyebab kesalahan dan kecurangan, namun demikian 
kecurangan dapat dideteksi dengan meningkatkan kemampuan independensi dan skeptisisme seorang auditor untuk menyajikan laporan keuangan yang dapat dipercaya.

Skeptisme profesional mewajibkan bahwa audit harus dirancang sedemikian rupa agar dapat memberikan keyakinan yang tinggi dan memadai untuk mendeteksi baik kekeliruan maupun kemungkinan terdapat kecurangan yang bersifat material dalam laporan keuangan (Silalahi, 2013). Seorang auditor yang skeptis tidak akan langsung menerima pendapat yang diajukan klien melainkan pendapat tersebut akan diresapi dan dicocokan dengan bukti dan konfirmasi mengenai obyek yang sedang dipermasalahkan. Jika tidak cocok dengan pernyataan klien, maka auditor berhak mengajukan beberapa pertanyaan untuk klien (Noviyanti, 2008). Sikap skeptisme ini penting dimiliki untuk lebih waspada terhadap bukti audit yang bersifat kontradiksi, jadi bukti audit dapat dievaluasi lebih lanjut dan membuat penaksiran yang lebih kritis.

Dalam Standar Profesi Akuntan Publik (SPAP,2011), menyatakan bahwa, skeptisme profesional auditor sebagai suatu sikap yang mencakup pikiran yang selalu mempertanyakan dan melakukan evaluasi secara kritis terhadap bukti. Hal ini akan mempengaruhi pada hasil dari suatu laporan keuangan auditan perusahaan sehingga laporan keuangan tersebut menunjukkan informasi atau opini yang tepat.

Selain skeptisisme Profesional, dalam pendeteksian berbagai macam kecurangan, auditor perlu meningkatkan independensi untuk menyajikan informasi yang baik dan dapat digunakan oleh pengguna. Independensi merupakan suatu cerminan sikap dari seorang auditor untuk tidak memilih pihak siapapun dalam melakukan audit. Independensi adalah sikap mental seorang auditor dimana ia dituntut untuk bersikap jujur dan tidak memihak sepanjang pelaksaan audit dan dalam memposisikan dirinya (Abdul,2008:46). Dengan sikap independen diharapkan auditor terhindar dari kepentingan pribadi, penelahaan pribadi, advokasi, dan intimidasi sehingga auditor dapat mendeteksi ada atau tidaknya kecurangan tersebut terdeteksi, auditor tidak ikut terlibat dalam mengamankan praktik kecurangan tersebut.

Berdasarkan latar belakang di atas, maka perumusan penelitian ini sebagai berikut : bagaimana pengaruh Skeptisme Profesional dan Independensi terhadap kemampuan auditor dalam mendeteksi kecurangan.

\section{Tinjauan Pustaka}

\subsection{Skeptisme Profesional Auditor}

Skeptisme profesional sangat diperlukan dalam proses audit, juga merupakan sikap yang harus dimiliki auditor dalam melakukan audit laporan keuangan auditee untuk mempertanyakan sekaligus mengevaluasi dan tidak langsung mempercayai bukti-bukti audit yang telah dikumpulkan selama proses audit. Skeptisme profesional adalah sikap yang mencakup pikiran yang selalu mempertanyakan dan melakukan evaluasi secara kritis terhadap bukti audit. Auditor menggunakan pengetahuan, keterampilan, dan kemampuan yang dituntut oleh profesi akuntan publik untuk melaksanakan dengan cermat dan seksama, dengan maksud dan integritas, pengumpulan bukti audit secara objektif (Standar Profesional Akuntan Publik 2001 Seksi 230 ).

menurut Fullerton dan Dutschi (2003:17) mengembangkan model sebagai indikator dalam mengukur skeptisme profesional, terdapat enam karakteristik utama yang dimiliki seorang auditor saat melakukan dan menerapkan sikap skeptisme profesional, yaitu:

1) Karakteristik yang berkaitan dengan pengujian bukti audit: 
a) Questioning Mind (pola pikir yang selalu bertanya-tanya)

b) Suspension of Judgment (Penundaan pengambilan keputusan)

c) Search for knowledge (Mencari pengetahuan)

2) Karakteristik yang berkaitan dengan pemahaman bukti audit:

a) Interpersonal understanding (pemahaman interpersonal)

3) Karakteristik yang berkaitan dengan inisiatif auditor untuk bersikap skeptisme berdasarkan bukti audit yang diperoleh:

a) Self confidence (percaya diri)

b) Self determination (Keteguhan hati)

Dalam penerapannya, skeptisme merupakan hal untuk menunjukan objektivitas dalam mencari informasi terkait dengan bukti audit. Skeptisme bukan berarti tidak mempercayai pernyataan auditee, melainkan sifat kehati-hatian untuk selalu berusaha mencari tahu semua informasi yang dibutuhkan. Dengan mempertanyakan suatu informasi yang didapatkannya dari entitas terkait apakah informasi yang didapat masuk akal dan sesuai dengan aturan yang berlaku serta berusaha untuk selalu mendapatkan informasi yang akurat. Dikatakan bahwa sikap skeptisme profesional berarti berpikiran yang selalu mempertanyakan (Questioning mind) terhadap setiap bukti yang diperoleh dalam pelaksanaan audit. Karakteristik skeptisme ini dibentuk dari beberapa indikator yang mendukung skeptisme profesional seorang auditor untuk mampu mendeteksi kecurangan, yaitu auditor selalu mempertanyakan pembuktian suatu objek audit dan selalu menolak pernyataan tanpa pembuktian yang jelas.

Dalam penemuan informasi baru tentu saja seorang auditor tidak langsung mengambil keputusan, akan tetapi auditor yang skeptis akan melakukan penundaan pengambilan keputusan sebelum semua informasi yang diterima dapat menunjukan informasi yang valid untuk mendukung pertimbangan (Suspension of Judgement). Dalam penerapannya, auditor yang melakukan penundaan dalam pengambilan keputusan berusaha untuk selalu memenuhi informasi yang lengkap sebelum membuat keputusan, sehingga memungkinkan penundaan dalam pengambilan keputusan bila informasi yang didapatkan belum valid.

Dalam proses audit, karakteristik yang mencerminkan skeptisme profesional yaitu, auditor mencari informasi yang up to date yang menunjukkan bahwa seorang auditor menemukan kepuasan bila menemukan informasi baru (Searching for knowledge) yang didasari oleh rasa keingintahuan.

Berkaitan dengan bukti audit yang didapat, seorang auditor harus memiliki pemahaman bukti audit yang disebut pemahaman interpersonal (Interpersonal Understanding). Pemahaman Interpersonal terbentuk dari pemahaman tujuan, motivasi, serta integritas dari penyedia informasi, dimana auditor berusaha untuk memahami perilaku dari penyedia informasi dan memahami alasan dari orang tersebut mengapa berperilaku demikian.

Tidak terlepas dari itu, sikap Skeptisme Profesional memiliki karakteristik yang berkaitan dengan inisiatif auditor yaitu seperti kepercayaan diri (Self Confidence) dalam bertindak terhadap bukti informasi yang dikumpulkannya, sehingga selalu mempertimbangkan pernyataan dari penyedia informasi yang bertujuan agar dapat memecahkan masalah yang berhubungan dengan informasi yang tidak konsisten.

Keteguhan hati (Self Determination) juga merupakan bagian dari inisiatif auditor untuk bersikap skeptisme profesional yang membuat auditor tidak terpengaruh oleh orang lain terhadap suatu hal yang berhubungan dengan bukti audit. 


\subsection{Independensi}

Independensi seorang auditor merupakan suatu dasar dari kepercayaan klien dan pengguna laporan keuangan terhadap profesi auditor dan sebagai sarana untuk menilai nilai mutu dari jasa audit. Dalam penerapannya, Independensi memiliki beberapa jenis yang dijelaskan menurut Alvin A. Arens yang dialih bahasakan oleh Herman Wibowo (2011) diantaranya yaitu :

1. Independence infact (independensi senyatanya)

2. Independence in appearance (independensi dalam penampilan)

3. Independence in competence (independensi dari keahlian atau kompetensinya).

Independen senyatanya (independence in fact), merupakan sikap independen yang dimiliki oleh seorang auditor, dimana dalam pelaksanaan pencarian bukti audit, pengujian bukti audit, pelaksanaan evaluasi hasil pemeriksaan bukti audit dan penyusunan laporan audit tidak memihak terhadap suatu pihak. Auditor pun harus mampu dalam mempertahankan sikap dan keputusannya dalam merumuskan dan menyatakan pendapatnya yang didukung dengan tingkat objektifitas yang tinggi sebagai dasar dalam mempertimbangkan fakta-fakta yang ditemukannya dalam proses audit.

Auditor harus menghapuskan pandangan orang lain yang dapat membuat auditor tersebut diragukan kebebasannya dalam penugasan audit, dimana suatu interpetasi pihak lain mengenai sikap independensi auditor yang disebut dengan Indepedensi dalam penampilan (Independence in Appearance). Seorang auditor dianggap tidak independensi jika auditor tersebut memiliki hubungan kekeluargaan, kerabat atau hubungan keuangan dengan pihak entitas yang diaudit serta pihak lainnya yang berhubungan dengan pekerjaanya sebagai auditor. Dengan adanya hubungan tertentu dengan pihak lain, maka dapat menimbulkan kecenderungan bahwa auditor memihak pada salah satu pihak dan tentunya dapat dikatakan bahwa auditor tersebut tidak menerapkan sikap yang independen.

Auditor juga harus menerapkan sikap independensi sesuai dengan keahliannya atau yang dapat disebut dengan Independensi dari keahlian atau kompetensinya (Independence in Competence). Dimana bertujuan untuk dapat meningkatkan nilai mutu dari jasa audit yang ditugaskan kepadanya, terkait erat dengan kompetensi, kemampuan dan kecakapan profesional auditor dalam mengerjakan tugas pokoknya.

\subsection{Pendeteksian Kecurangan}

Pada dasarnya tindak kecurangan dapat dibongkar oleh auditor karena adanya indikasi awal serta perencanaan yang baik untuk menyingkap segala sesuatu mengenai tindak kecurangan yang mungkin terjadi, tim audit serta auditor harus memiliki intuisi yang tajam melihat berbagai aspek laporan keuangan auditee yang rawan terjadi kecurangan. Mendeteksi kecurangan adalah upaya untuk mendapatkan indikasi awal yang cukup mengenai tindak kecurangan, sekaligus mempersempit ruang gerak para pelaku kecurangan (yaitu ketika pelaku menyadari prakteknya telah diketahui, maka sudah terlambat untuk berkelit (Kumaat, 2011:156). Dan Auditor memiliki peran serta fungsi untuk berupaya meminimalisir serta menghilangkan sebab- sebab timbulnya kecurangan guna pencegahan terjadinya kecurangan.

\subsection{Kerangka Pemikiran dan Pengembangan Hipotesis}

Skeptisme professional merupakan hal yang penting dalam mendeteksi kecurangan atas laporan keuangan, karena seorang auditor tidak akan begitu saja percaya terhadap penjelasan klien dan akan mengajukan beberapa pertanyaan untuk mengumpulkan bukti yang 
relevan terhadap objek yang sedang diteliti. Skeptisme professional yang rendah menumpulkan kepekaan auditor dalam mendeteksi kecurangan baik yang nyata maupun yang berupa potensi, atau terhadap tanda-tanda bahaya (red flags, warning signs) yang mengindikasi adanya kesalahan (accounting error) dan kecurangan (fraud) (Tuannakota,2011:77). SAS 1 (AU230) mensyaratkan bahwa audit dirancang sedemikian rupa supaya dapat memberikan kepastian yang layak untuk mendeteksi baik kekeliruan maupun kecurangan yang material dalam laporan keuangan. Untuk tercapainya pendeteksian kecurangan, proses audit harus di rencanakan dan dilaksanakan dengan sikap skeptisisme professional atas semua aspek penugasan Alvin Arens (2012:186). Menurut Fullerton dan Durtschi (2004) dalam Eko Ferry Anggriawan (2014) auditor yang memiki sikap skeptisisme profesional yang tinggi akan membuat auditor tersebut untuk selalu mencari informasi yang lebih banyak dan lebih signifikan dari pada auditor yang memiliki tingkat skeptisme profesional yang rendah, dan hal ini mengakibatkan auditor yang memiliki tingkat skeptisme profesional yang tinggi akan lebih dapat mendeteksi adanya fraud karena informasi yang mereka miliki tersebut. Dengan demikian, semakin besar skeptisisme profesional seorang auditor maka semakin tinggi tingkat kemampuan dalam upaya mendeteksi kecurangan.

Disamping skeptisisme, Independensi auditor penting supaya tidak mudah untuk dipengaruhi oleh pihak lain yang berhubungan dengan tugasnya. Auditor tidak dibenarkan untuk memihak kepada pihak manapun. Auditor mempunyai kewajiban untuk berlaku jujur tidak hanya kepada manajemen entitas maupun kepada pemilik perusahaan, namun juga kepada kreditur, pengguna hasil auditan laporan keuangan serta pihak-pihak yang meletakkan kepercayaannya kepada profesi auditor, Setyaningrum (2010:34). Oleh karena itu cukuplah beralasan, bahwa untuk menghasilkan audit yang berkualitas dan melakukan pendeteksian kecurangan diperlukan sikap independen dari auditor. Karena jika auditor kehilangan independensinya maka laporan audit yang dihasilkan tidak sesuai dengan kenyataan yang ada maka ada kemungkinan terdapat suatu tingkat salah saji yang material dalam pengauditan laporan keuangan tersebut sehingga tidak dapat digunakan sebagai dasar pengambilan keputusan.

Aspek-aspek independensi berupa kejujuran yang muncul dari dalam diri auditor dalam mempertimbangkan fakta-fakta yang ada dan terjadi di dalam laporan entitas yang diauditnya, dapat dijadikan sebagai hubungan atau keterkaitan Independensi terhadap pendeteksian kecurangan pada laporan keuangan yang dilakukan oleh auditor. Aspek yang disebutkan diatas, yaitu independensi dalam kenyataannya (Independence in fact), bisa diartikan bahwa independensi dalam kenyataannya ialah bila auditor menemukan kesalahan atau ketidakbenaran dalam fakta atau temuan yang didapat pada laporan keuangan manajemen entitas yang diauditnya, maka auditor harus mengungkapkan fakta yang sesuai dengan yang ditemukannya. Selain itu, auditor yang independen dapat meningkatkan integritas dan efisiensi dalam pembuatan laporan hasil audit untuk digunakan oleh pengguna laporan tersebut.

\section{Metode Penelitian}

Metode penelitian yang digunakan adalah metode deskriptif kuantitatif dan verifikatif, dengan teknik pengumpulan data yang bersifat primer melalui penyebaran kuesioner kepada KAP di kota Bandung yang telah memenuhi syarat pertimbangan peneliti. Pengujian instrument penelitian dilakukan dengan uji validitas dan reliabilitas. Sedangkan untuk pengujian hipotesis digunakan analisis regresi berganda dengan persamaan sebagai berikut : 
$\mathrm{PK}=\alpha+\beta 1 \mathrm{SP}+\beta 2 \mathrm{IN}+\mathrm{e}$

Keterangan:

PK : Pendeteksian kecurangan

$\alpha:$ Konstanta

$\beta 1 \ldots . \beta \mathrm{n}:$ Koefisien arah regresi

SP : Skeptisme Profesional

IN : Independensi

e : Kesalahan pengganggu (error)

\section{Pembahasan}

\subsection{Hasil Pengujian Koefisien Regresi Secara Bersama-sama}

Uji signifikansi digunakan untuk mengetahui apakah variabel independen secara bersama sama atau simultan yang dimasukkan ke dalam model regresi dapat mempengaruhi variabel dependen atau tidak. Pengujian ini menggunakan tingkat signifikan. Berikut ini hasil analisis menggunakan program SPSS versi 22 yang disajikan dalam tabel 4.1 sebagai berikut:

\section{Tabel 4.1}

Pengujian Secara Simultan (Uji F)

ANOVA $^{\mathrm{a}}$

\begin{tabular}{|c|c|c|c|c|c|c|}
\hline & & $\begin{array}{l}\text { Sum of } \\
\text { Squares }\end{array}$ & df & Mean Square & $\mathrm{F}$ & Sig. \\
\hline \multirow[t]{3}{*}{1} & Regression & 8182.489 & 2 & 4091.245 & 355.130 & $.000^{\mathrm{b}}$ \\
\hline & Residual & 368.654 & 32 & 11.520 & & \\
\hline & Total & 8551.143 & 34 & & & \\
\hline
\end{tabular}

a. Dependent Variable: Pendeteksian Kecurangan

b. Predictors: (Constant), Independensi, Skeptisme Profesional

Sumber : Hasil Pengolahan SPSS versi 22, 2019

Berdasarkan pada tabel 4.28 yang merupakan hasil uji simultan (uji F), diperoleh nilai signifikansi sebesar 0.000 lebih kecil dari tingkat signifikan 0.05 , hal ini menunjukkan bahwa model dapat digunakan untuk pengujian antara variabel Skeptisme Profesional (X1) dan Independensi (X2) terhadap Pendeteksian Kecurangan (Y) yang dapat berpengaruh secara simultan.

\section{Perhitungan Koefisien Determinasi}

Koefisien determinasi menunjukkan besarnya pengaruh variable bebas terhadap variable tidak bebas. Dari hasil pengolahan data dengan software SPSS for windows diperoleh nilai $\mathrm{R}^{2}$ seperti yang disajikan berikut :

Tabel 4.2

Hasil Uji Koefisien Determinasi

Model Summary
\begin{tabular}{|l|c|r|r|r|}
\hline & & & & \\
Model & R & R Square & Adjusted R Square & Std. Error of the Estimate \\
\hline 1 & $.978^{\mathrm{a}}$ & 0.957 & 0.954 & 3.39418 \\
\hline
\end{tabular}

a. Predictors: (Constant), Skeptisme Profesional, Independensi

b. Dependent Variable: Pendeteksian Kecurangan

Sumber : Hasil Pengolahan SPSS versi 22, 2018 
Berdasarkan hasil perhitungan di atas, diperoleh nilai $\mathrm{R}=0.957$, nilai ini menunjukkan adanya hubungan yang sangat kuat antara variabel independen secara simultan dengan variabel dependen. Nilai koefisien determinasi $\left(\mathrm{R}^{2}\right)$ sebesar 0.957 menunjukkan bahwa Skeptisme Profesional dan Independensi secara simultan berpengaruh sebesar 95.7\% terhadap Pendeteksian Kecurangan. Nilai sisa sebesar $4.3 \%$ dipengaruhi oleh faktor lain yang tidak diteliti oleh peneliti.

\subsection{Hasil Pengujian Koefisien Regresi Secara Parsial}

Pengujian ini bertujuan untuk mengetahui secara individual besarnya pengaruh Skeptisme Profesional sebagai variabel independen (X1) dan Independensi sebagai variabel independen (X2) terhadap Pendeteksian Kecurangan sebagai variabel dependen (Y) dengan menggunakan perbandingan nilai signifikansi, apabila nilai signifikansi yang dihasilkan < 0,05 maka dapat disimpulkan bahwa secara parsial variabel independen berpengaruh secara signifikansi terhadap variabel dependen. Berikut ini hasil uji parsial (uji t) dengan menggunakan program SPSS versi 22 disajikan dalam tabel 4.2 sebagai berikut :

Tabel 4.3

Pengujian Secara Parsial (Uji t)

Coefficients $^{\mathrm{a}}$

\begin{tabular}{|c|c|c|c|c|c|}
\hline \multirow[t]{2}{*}{ Model } & \multicolumn{2}{|c|}{$\begin{array}{l}\text { Unstandardized } \\
\text { Coefficients }\end{array}$} & \multirow{2}{*}{$\begin{array}{l}\text { Standardized } \\
\text { Coefficients } \\
\text { Beta } \\
\end{array}$} & \multirow[b]{2}{*}{$\mathrm{t}$} & \multirow[b]{2}{*}{ Sig. } \\
\hline & $\mathrm{B}$ & Std. Error & & & \\
\hline (Constant) & 6.339 & 3.217 & & -1.970 & .058 \\
\hline Skeptisme Profesional & 1.179 & 0.135 & 0.902 & 8.704 & .000 \\
\hline Independensi & 0.151 & 0.193 & 0.081 & 0.781 & .441 \\
\hline
\end{tabular}

a. Dependent Variable: Pendeteksian Kecurangan

Sumber : Sumber : Hasil Pengolahan SPSS versi 22, 2019

1. Pengaruh Skeptisme terhadap Pendeteksian Kecurangan

Berdasarkan hasil analisis data diketahui bahwa skeptisme professional berpengaruh terhadap kemampuan auditor dalam mendeteksi kecurangan. beberapa auditor yang bekerja pada Kantor Akuntan Publik (KAP) di Kota Bandung memiliki skeptisme professional yang baik dalam menjalankan pekerjaannya. Penggunaan maupun pengambilan keputusan yang tepat dan efektif dapat membantu auditor untuk mencapai tujuan dalam meraih keberhasilan kerja. Dalam hal pekerjaan auditor harus mampu mengaudit laporan keuangan dengan skeptisme yang professional. Hal ini memberikan bukti bahwa dengan adanya skeptisme professional pada diri auditor akan berpengaruh terhadap kemampuan auditor dalam mendeteksi kecurangan

2. Pengaruh Independensi Auditor dalam Pendeteksian Kecurangan

Berdasarkan hasil analisis data diketahui bahwa independensi auditor tidak berpengaruh terhadap kemampuan auditor dalam mendeteksi kecurangan. hasil penelitian ini ditolak karena mungkin auditor tidak mampu menjaga tingkat independensinya agar tetap sesuai dengan jalur yg seharusnya. Auditor di Kantor Akuntan Publik Kota Bandung masih memiliki ketergantungan dengan klien yang mereka audit, sehingga klien yang diaudit tidak hanya menyampaikan informasi atas bukti audit, melainkan ikut campur tangan dalam program audit dan menentukan 
subjek pemeriksaan. Kerjasama klien yang terlalu lama juga akan menimbulkan kerawanan atas independensi yg dimiliki auditor. Belum lagi berbagai fasilitas yang disediakan klien selama penugasan audit untuk auditor. Tingginya independensi belum tentu dapat memperbesar kemampuan auditor dalam mendeteksi kecurangan.

\section{Kesimpulan}

1. Skeptisme Profesional auditor berpengaruh secara signifikan terhadap kemampuan auditor dalam mendeteksi kecurangan pada 16 Kantor Akuntan Publik di Kota Bandung. Artinya, semakin tinggi tingkat skeptisme profesional auditor maka akan semakin meningkatkan kemampuan auditor dalam mendeteksi kecurangan.

2. Independensi auditor tidak berpengaruh secara signifikan terhadap kemampuan auditor dalam mendeteksi kecurangan pada 16 Kantor Akuntan Publik di Kota Bandung. Artinya, dengan ada atau tidaknya independensi yang dimiliki auditor dalam mendeteksi kecurangan tidak akan berpengaruh terhadap kemampuan auditor dalam mendeteksi kecurangan.

\section{DAFTAR PUSTAKA}

AICPA,SAS No. 99. 2002 Consideration of Fraud in a Financial Statement Audit, AICPA. New York

Anggriawan, Eko Ferry. 2014. Pengaruh Pengalaman Kerja, Skeptisme Profesional dan Tekanan Waktu Anggaran terhadap Kemampuan Auditor dalam Mendeteksi Kecurangan (Fraud). Semarang: Universitas Katolik Soegijapranata.

Arens, Alvin A. Randal J. Elder dan Mark S. Beasley. 2014. Auditing dan Jasa Assurance (terjemahan). Edisi kelimabelas. Jakarta: Erlangga.

Arikunto, S. 2006. "Prosedur Penelitian”.Jakarta: P.T Rineka Cipta.

Biksa, Ida Ayu Indira., I Dewa Nyoman Wiratmaja. 2016. Pengaruh Pengalaman, Independensi, Skeptisme Profesional Auditor Pada Pendeteksian Kecurangan. E-Journal Akuntansi Universitas Udayanan. Vol 17.3

Elfarini, Eunike Christina. 2007. Pengaruh Kompetensi dan Independensi Auditot Terhadap Kualitas Audit. Penelitian Universitas Negeri Semarang.

Erna Widyatuty dan Rahmat Febroyamto. 2010. Pengukuran Kualitas Audit: Sebuah Esai. Jurnal Ilmiah Akuntansi dan Bisnis Vol. 5 No. 2.

Fullerton, rosenary R., and Durtshci, Cindy. 2003. The Effect of Profesiona Skepticism on The Fraud Detection Skills of Internal Auditors. Working Paper Series. March 5, 2012,

Ghozali, Imam. 2013. Aplikasi Analisis Multivariate Dengan Program SPSS. BPUniversitas Diponogoro, Semarang.

Hartan Hanum Trinanda, 2016. Pengaruh Skeptisme Profesional dan Independensi Auditor terhadap Kemampuan Auditor dalam Mendeteksi Kecurangan. Lumbung Pustaka UNY.

Ikatan Akuntansi Indonesia. 2001. Standar Profesionalisme Akuntan Publik. Jakarta: Salemba Empat.

KBBI, 2016. Kamus Besar Bahasa Indonesia (KBBI) [online] Available at : www.kbbi.web.id [ Diakses tanggal 23 Oktober 2018] 
Noviyanti S. 2008. Skeptisme Profesional Auditor dalam Mendeteksi Kecurangan. Jurnal Akuntansi dan Keuangan Indonesia Vol 5 No. 1.

Reksokjoedo, 2013. Bagaimana Mencegah dan Menangani Kecurangan di Perusahaan Anti Fraud. Yogyakarta: Bahari Press.

Sekaran, Uma. 2014. Research Methods for Business: A Skill Building Approach. New Jersey: John Willey \& Son

Setyaningrum, 2010. Pengaruh Independensi dan Kompetensi Auditor terhadap Tanggung Jawab Auditor dalam Mendeteksi Kecurangan dan Kekeliruan Laporan Keuangan. Sekolah Tinggi Ilmu Ekonomi Perbanas, Surabaya.

Silalahi Sem Paulus, 2013. Pengaruh Etika, Kompetensi, Pengalaman Auditor dan Situasi Audit terhadap Skeptisme Profesional Auditor. Jurnal Ekonomi Vol, 21 No 3 September 2013.

Siti Resmi. 2009. Perpajakan: Teori dan Kasus. Jakarta: Salemba Empat.

SPKN (Standar Pemeriksaan Keuangan Negara). Peraturan BPK RI No 01 Tahun 2017. Fitama Binbangkum BPK RI

Subijanto. 2010. Profesionalisme Auditor dan Kompetensi Auditor. Jakarta, Rineka Cipta.

Sugiyono. 2014. Metode Penelitian Bisnis. Bandung: CV Alfabeta

Tuanakkota, Theodorus M. 2007. Akuntansi Forensik dan Audit Investigatif. Jakarta: Lembaga Penerbit Fakultas Ekonomi Universitas Indonesia.

Umi Narimawati. 2010. Penulisan Karya Ilmiah. Jakarta: Penerbit Genesis.

Wiguna Floreta, 2015. Pengaruh Skeptisme dan Independensi Auditor terhadap Pendeteksian Kecurangan (Survei Pada Auditor KAP di Malang). EProceding of Management Vol 2, No.1 .

Wirakusumah Arifin, dan Agoes Sukrisno. 2003. Tanya-Jawab Auditing. Jakarta, Fakultas Ekonomi Universitas Indonesia

www.cnnindonesia.com [Diakses tanggal 20 Oktober 2018]

www.finance.detik.com [Diakses tanggal 18 Oktober 2018] 
Maulana Aji Prasetyo, et al 